\title{
ANALISIS HASIL BELAJAR SISWA PADA MATERI PERBANDINGAN BERDASARKAN RANAH KOGNITIF REVISI TAKSONOMI BLOOM
}

\author{
Dwi Oktaviana ${ }^{1}$, Iwit Prihatin ${ }^{2}$ \\ ${ }_{1,2}$ Program Studi Pendidikan Matematika, IKIP PGRI Pontianak \\ dwi.oktaviana7@gmail.com ${ }^{1}$, iwitprihatin82@gmail.com ${ }^{2}$
}

\begin{abstract}
This research to classify the most comparison and described the results of the study grade VII B students SMP Koperasi Pontianak the academic year 2017/2018, based on cognitive Revised Bloom's Taxonomy. Research method used is descriptive method with a qualitative approach. The subjects of this research were students of class VII B with high and low ability levels. The instruments in this research were daily test questions and student answer sheets on the subject of comparison and interview guidelines. Based on the results of research, obtained the percentage classifications about $20 \%$ for understand (C2) and $80 \%$ for apply (C3). Students' mathematics learning outcomes based on cognitive domains Revised Bloom's Taxonomy is that students are better able to solve problems with an understanding indicator of $60 \%$ than the problem with the indicator applying at $19.2 \%$. Students with high ability to achieve indicators understand and apply while students with low abilities do not reach both indicators.
\end{abstract}

Key Word: learning outcomes, ability level, revised bloom's taxonomy, comparison

\section{PENDAHULUAN}

Pembelajaran merupakan hal penting dalam dunia pendidikan, menurut Undang-Undang Nomor 20 tahun 2003 tentang Sisdiknas, pembelajaran adalah proses interaksi peserta didik dengan pendidik dan sumber belajar lainnya (Karwono, 2012:19). Pembelajaran juga dapat diartikan sebagai suatu proses yang/diupayakan agar peserta didik dapat mengoptimalkan potensi yang dimiliki baik kognitif, afektif, maupun psikomotorik secara efektif dan efesien untuk mencapai perubahan perilaku yang diharapkan. Pembelajaran di sekolah memiliki empat hal yang perlu diperhatikann yaitu perencanaan, pelaksanaan, evaluasi, dan pengawasan. Sebagaimana disebutkan dalam PP. No. 19 tahun 2005 tentang Standar Nasional Pendidikan pasal 19 ayat 3 yaitu "setiap satuan pendidikan melakukan perencanaan proses pembelajaran, pelaksanaan proses pembelajaran, penilaian hasil belajar, dan pengawasan. Oleh karena itu, evaluasi dalam pembelajaran sangat perlu diperhatikan.

Di akhir pada suatu proses pembelajaran akan diadakan evaluasi untuk mengetahui perkembangan dan hasil belajar siswa. Dalam sebuah pembelajaran, khususnya di kelas, guru adalah pihak yang paling bertanggung jawab terhadap hasil belajar siswa. Untuk menentukan hasil belajar dan kemajuan belajar siswa, guru sering menggunakan evaluasi sumatif. Evaluasi sumatif biasanya dilakukan ketika berakhirnya suatu pokok bahasan, tengah semester, dan akhir semester atau kenaikan kelas. Karena evaluasi sumatif ini adalah evaluasi yang menentukan hasil belajar dan kemajuan kemampuan belajar siswa. Maka sebagai guru dituntut tidak hanya menentukan hasil belajar dari siswanya tetapi juga harus mampu menentukan kemajuan belajar siswanya. Sehingga guru hendaknya melakukan analisis terhadap hasil belajar siswanya untuk mengetahui kekurangan dan kemajuan kemampuan belajar para siswa.

Perolehan hasil belajar erat kaitanya dengan kemampuan mengolah informasi pada materi yang dipelajari siswa pada kawasan kognitifnya. Kawasan kognitif adalah kawasan yang membahas tujuan pembelajaran berkenaan dengan proses mental yang berawal dari tingkat mengingat sampai mencipta (Uno dan Koni, 2012:60).

Namun kenyataan yang terjadi, penilaian yang dilakukan oleh guru dalam melihat hasil belajar siswa hanya secara kuantitatif yakni berupa nilai. Guru hanya memberikan soal-soal tes evaluasi untuk dikerjakan oleh 
siswa kemudian jawaban siswa akan dikoreksi untuk memperoleh nilai. Jika nilai siswa telah mencapai nilai kriteria ketuntasan minimal (KKM), maka siswa tersebut dinyatakan telah menguasai materi yang diajarkan. Asumsi tersebut tidak sepenuhnya bisa dikatakan benar karena pada hakikatnya kemampuan siswa dalam menjawab setiap soal memiliki tingkat kedalaman pemahaman yang berbeda-beda. Kemampuan siswa yang beragam dalam menyerap materi seharusnya didukung dengan pemberian soal yang dapat mengorganisasikan keterampilan berpikir kognitif siswa.

Penelitian yang dilakukan oleh Giani (2015) meneliti tentang tingkat kognitif soal-soal buku teks matematika. Hasil penelitiannya menunjukkan bahwa persentase soal untuk masing-masing tingkat kognitif adalah: $\mathrm{Cl}$ $(3,23 \%)$, C2 (30,97\%), C3 (61,93\%), C4 (3,87\%), C5 $(0 \%)$, C6 $(0 \%)$. Hasil tersebut belum memenuhi proporsi soal yang mendukung ketercapaian Kompetensi Dasar, yaitu 30\% untuk C1 dan C2 (mengingat kembali dan memahami), 40\% untuk C3 dan C4 (mengaplikasikan) dan menganalisis), dan 30\% untuk C5 dan C6 (sintesis dan mencipta). Ketepatan hasil belajar siswa sangat erat hubungannya dengan aspek kognitif siswa. Untuk keperluan tersebut beberapa pakar pendidikan di Amerika Serikat mengembangkan suatu metode pengklasifikasikan pendidikan yang disebut taxonomy.

Taksonomi ialah klasifikasi atau pengelompokan benda menurut ciri-ciri tertentu. Taksonomi dalam bidang pendidikan, digunakan untuk klasifikasi tujuan instruksional; ada yang menamakannya tujuan pembelajaran, tujuan penampilan, atau sasaran belajar, yang digolongkan dalam tiga klasifikasi umum atau ranah (domain), yaitu: (1) ranah kognitif, berkaitan dengan tujuan belajar yang berorientasi pada kemampuan berpikir; (2) ranah afektif berhubungan dengan perasaan, emosi, sistem nilai, dan sikap hati; dan (3) ranah psikomotor (berorientasi pada keterampilan motorik atau penggunaan otot kerangka). Beberapa model taksonomi tujuan pendidikan yang dapat digunakan untuk membantu dalam melakukan evaluasi hasil belajar adalah taksonomi bloom revisi.
Taksonomi bloom menguraikan enam tingkat respon dalam proses berpikir yaitu: (1) pengetahuan (knowledge), (2) pemahaman (comprehension), (3) penerapan (application) (4) Analisis (analysis), (5) sintesis (synthesis), (6) penilaian (evaluation). Tingkatantingkatan dalam taksonomi tersebut telah digunakan hampir setengah abad sebagai dasar untuk penyusunan tujuan-tujuan pendidikan, penyusunan tes dan kurikulum. Revisi dilakukan terhadap Taksonomi Bloom, yakni perubahan dari kata benda (dalam Taksonomi Bloom) menjadi kata kerja (dalam Revisi Taksonomi Bloom). Perubahan ini dibuat agar sesuai dengan tujuan-tujuan pendidikan. Tujuan-tujuan pendidikan mengindikasikan bahwa siswa akan dapat melakukan sesuatu (kata kerja) dengan sesuatu (kata benda).

Menurut taksonomi bloom revisi, kemampuan berpikir kognitif dapat diklasifikasikan menjadi enam kategori. Ranah kognitif yang telah direvisi Anderson dan Kratwohl (2010: 66-88) yakni terdiri dari mengingat (remember), memahami atau mengerti (understand), menerapkan (apply), menganalisis (analyze), mengevaluasi (evaluate), dan menciptakan (create).

Adapun, proses mengingat (remember) adalah mengambil pengetahuan yang dibutuhkan dari memori jangka panjang. Kategori mengingat terdiri dari proses kognitif mengenali dan mengingat kembali. Untuk menilai mengingat, siswa diberi soal yang berkaitan dengan proses kognitif mengenali dan mengingat kembali. Memahami (understand) adalah proses kognitif yang berpijak pada kemampuan transfer dan ditekankan di sekolah-sekolah dan perguruan-perguruan tinggi. Proses-proses kognitif dalam kategori memahami meliputi menafsirkan, mencontohkan, mengklasifikasikan, merangkum, menyimpulkan, membandingkan dan menjelaskan. Proses kognitif mengaplikasikan (apply) melibatkan penggunaan prosedur-prosedur tertentu untuk mengerjakan soal latihan atau menyelesaikan masalah. Kategori mengaplikasikan terdiri dari dua proses kognitif, yakni mengeksekusi (ketika tugasnya hanya soal latihan) dan 
mengimplementasikan (ketika tugasnya merupakan masalah)

Menganalisis (analyze) melibatkan proses memecahmecah materi jadi bagian- bagian kecil dan menentukan bagaimana hubungan antar bagian dan antara setiap bagian dan struktur keseluruhanya. Kategori proses menganalisis ini meliputi proses-proses kognitif membedakan, mengorganisai, dan mengatribusikan. Mengevaluasi (evaluate) didefinisikan sebagai membuat keputusan berdasarkan kriteria dan standar. Kategori mengevaluasi mencakup proses-proses kognitif memeriksa (keputusan-keputusan diambil berdasarkan kriteria internal) dan mengkritik (keputusan-keputusan yang diambil berdasarkan kriteria eksternal). Mencipta (create) melibatkan proses menyusun elemen-elemen jadi sebuah keseluruhan yang koheren atau fungsional. Mencipta berisikan tiga proses kognitif: merumuskan, merencanakan, dan memproduksi

Sehingga jika penilaian dari guru hanya secara kuantitatif maka belum bisa diketahui sejauh mana proses berpikir siswa. Sedangkan untuk mengetahui pencapaian hasil belajar pada proses kognitif siswa dapat dengan menggunakan taksonomi bloom revisi seperti yang telah disebutkan, sehingga jika ditinjau lebih jauh lagi hal tersebut juga dapat digunakan sebagai bahan pertimbangan untuk lebih mengoptimalkan kegiatan pembelajaran yang berlangsung dikelas.

Oleh karena itu, peneliti bertujuan untuk mendeskripsikan dan menganalisis klasifikasi soal ulangan harian matematika serta hasil belajar siswa berdasarkan ranah kognitif taksonomi bloom revisi.

\section{METODE PENELITIAN}

Penelitian ini merupakan penelitian kualitatif. Jenis penelitian yang digunakan dalam penelitian ini yaitu deskriptif. Penelitian deskriptif bertujuan untuk memaparkan dan menggambarkan fakta-fakta berdasarkan cara pandang tertentu. Penelitian ini ditujukan untuk mendeskripsikan dan menganalisis klasifikasi soal ulangan harian matematika serta hasil belajar siswa berdasarkan ranah kognitif taksonomi bloom revisi pada materi perbandingan

Penelitian ini dilaksanakan di SMP Koperasi Pontianak. Penentuan subjek penelitian dilakukan dengan menggunakan teknik purposive sampling. Adapun subjek penelitian adalah siswa kelas VII B SMP Koperasi Pontianak tahun ajaran 2017/2018 dengan kemampuan tinggi dan rendah. Teknik pengumpul data dalam penelitian ini adalah teknik dokumentasi dan teknik komunikasi langsung dengan alat pengumpul datanya berupa dokumentasi terkait hasil ulangan harian materi perbandingan pada semester genap tahun ajaran 2017/2018 dan pedoman wawancara. Teknik analisis data yang digunakann adalah reduksi data (data reduction), penyajian data (data display), dan penarikan kesimpulan (conclusion drawing). Untuk uji keabsahan data menggunakan triangulasi. Menurut Maleong (2006: 330), triangulasi adalah teknik pemerikasaan keabsahan data yang memanfaatkan sesuatu yang lain di luar data itu untuk keperluan pengecekan atau sebagai pembanding terhadap data itu. Untuk uji keabsahan data dalam penelitain ini menggunakan triangulasi teknik, yang berarti peneliti menggunakan teknik pengumpulan data yang berbeda-beda untuk mendapatkan data dari sumber yang sama. Peneliti menggunakan analisis data terhadap hasil ulangan harian siswa dan wawancara untuk mendapatkan data.

\section{HASIL DAN PEMBAHASAN}

Pengumpulan data pada penelitian ini dengan menggunakan metode dokumentasi untuk mengambil soal ulangan harian dan hasil pekerjaaan siswa pada materi perbandingan. Soal ulangan harian pada materi perbandingan kelas VII B di SMP Koperasi Pontianak tahun ajaran 2017/2018 berjumlah 5 soal. Analisis data dilakukan peneliti dengan berpedoman pada ranah kognitif Taksonomi Bloom Revisi menurut Anderson dan Krathwohl. Soal tersebut berbentuk uraian dengan klasifikasi yang disajikan pada tabel 1 berikut. 
Dwi Oktaviana ${ }^{1}$, Iwit Prihatin ${ }^{2}$ : Analisis Hasil Belajar Siswa pada Materi Perbandingan Berdasarkan Ranah Kognitif Revisi Taksonomi BLOOM

Tabel 1. Klasifikasi Soal Ulangan Harian Pada Materi Perbandingan Berdasarkan Ranah Kognitif Taksonomi Bloom Revisi

\begin{tabular}{lccc}
\hline Tingkat Kognitif & Nomor Soal & Jumlah Soal & Persentase \\
\hline Mengingat/remember $(\mathrm{C} 1)$ & - & 0 & $0 \%$ \\
Memahami/understand $(\mathrm{C} 2)$ & 4 & 1 & $20 \%$ \\
Menerapkan/apply (C3) & $1,2,3,5$ & 4 & $80 \%$ \\
Menganalisis/anali (C4) & - & 0 & $0 \%$ \\
Mengevaluasi (C5) & - & 0 & $0 \%$ \\
Berkreasi/Sintesis (C6) & - & 0 & $0 \%$ \\
\hline
\end{tabular}

understand dan indikator menerapkan atau apply. Adapun

Dari tabel 1 terlihat bahwa tingkat kognitif pada soal ulangan harian pada materi perbandingan kelas VII B di SMP Koperasi Pontianak tahun ajaran 2017/2018 dijelaskan sebagai sebagai berikut:

1. Ranah kognitif memahami (C2) terdapat 1 soal adalah soal nomor 4. Soal tersebut dikategorikan pada tingkat kognitif memahami (C2) karena soal tersebut menuntut siswa memahami konsep perbandingan serta memahami bahasa yang digunakan dalam soal.

2. Ranah kognitif menerapkan (C3) terdapat 4 soal yaitu nomor 1, 2, 3, dan 5. Secara umum soal tersebut dikategorikan pada tingkat kognitif menerapkan (C3) karena soal-soal tersebut mengharuskan siswa untuk dapat menerapkan konsep perbandingan dan menuntut siswa memilih konsep tertentu untuk menghitung serta menghubungkan antara dua informasi atau lebih.

Hasil penelitian tentang klasifikasi soal ulangan harian pada materi perbandingan menunjukkan bahwa soal yang dibuat memenuhi indikator pada Taksonomi Bloom Revisi yaitu pada indikator memahami atau soal ulangan harian dengan indikator apply lebih banyak daripada soal dengan indikator understand. Soal ulangan harian dengan indikator apply sebesar $80 \%$ sedangkan soal ulangan harian dengan indikator understand sebesar $20 \%$. Hal ini mengindikasikan bahwa soal ulangan harian yang dibuat oleh guru tentang perbandingan di kelas tersebut dimana siswa dituntut dapat menerapkan konsep perbandingan setelah memahami konsep dari perbandingan. Hal ini sesuai dengan penelitian yang dilakukan oleh Giani (2015) tentang analisis tingkat kognitif soal-soal buku teks matematika kelas VII berdasarkan Taksonomi Bloom menyatakan bahwa persentase soal untuk masing-masing tingkat kognitif adalah: C1 (3,23\%), C2 (30,97\%), C3 (61,93\%), C4 $(3,87 \%)$, C5 (0\%), C6 (0\%). Dari hasil penelitian tersebut terlihat bahwa dalam buku teks matematika yaitu soal-soal pada BSE Matematika juga banyak memuat soal berkaitan dengan indicator menerapkan atau C3.

Hasil belajar matematika siswa kelas VII B pada ulangan harian pada materi perbandingan berdasarkan ranah kognitif Taksonomi Bloom Revisi disajikan pada gambar 1 berikut.

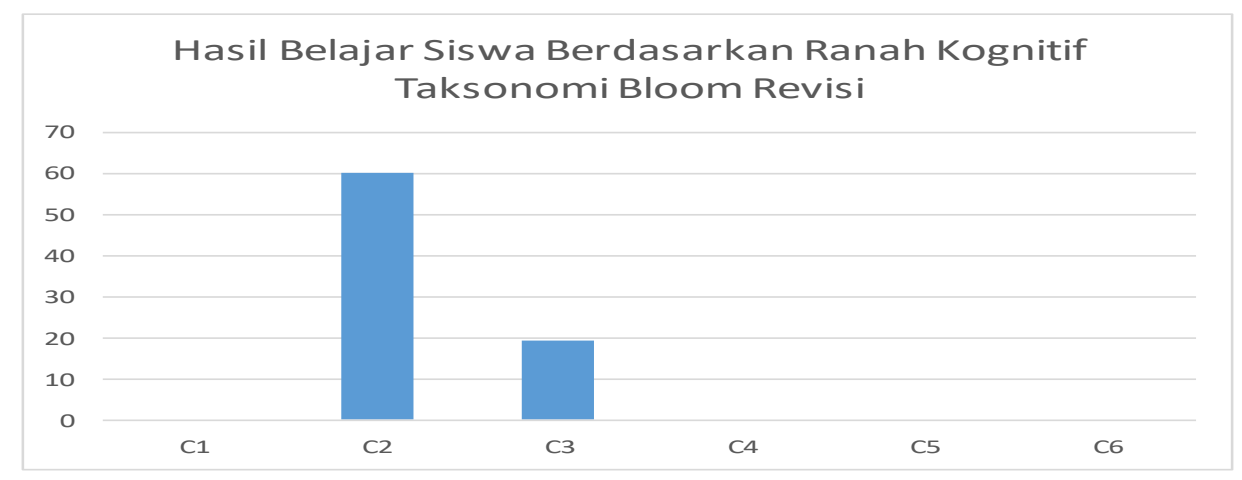

Gambar 1. Persentase Hasil Belajar Matematika Siswa Kelas VII B Berdasarkan Ranah Kognitif Taksonomi Bloom Revisi 
Berdasarkan gambar 1 dapat dilihat bahwa soal yang disajikan pada ulangan harian pokok bahasan perbandingan memuat ranah kognitif yaitu tingkat kognitif memahami $(\mathrm{C} 2)$ dan ranah kognitif menerapkan (C3). Rata-rata persentase ranah kognitif di kelas VII B sebagai berikut: (a) ranah kognitif memahami atau understand sebesar $60 \%$ dan (b) ranah kognitif indikator menerapkan atau apply sebesar 19,2\%. Hal ini mengindikasikan bahwa siswa hanya dapat dalam menyelesaikan soal ulangan harian pada indikator pemahaman sedangkan soal dengan indikator merapkan hanya sebagaian siswa yang dapat menyelesaikan soal.

Selanjutnya, dilakukan analisis terhadap hasil pekerjaan siswa guna untuk mengetahui tingkatan berpikir kognitif siswa berdasarkan Taksonomi Bloom Revisi. Subjek penelitian tidak dipilih secara acak, melainkan dengan sampel bertujuan (purposive sample). Subjek bertujuan memfokuskan pada informan-informan yang telah terpilih untuk dilakukan wawancara mendalam. Pemilihan subjek dalam penelitian ini diambil dari 25 siswa kelas VII B yang mengikuti tes tertulis dan telah diklasifikasikan berdasarkan interpretasi proses kognitif dalam taksonomi bloom revisi. Melalui pengelompokan tersebut, terpilih 2 siswa yang dijadikan sebagai subjek penelitian yaitu satu siswa dari kategori kemampuan tinggi (S4) dan satu siswa dari kategori kemampuan rendah $(\mathrm{S} 16)$.

Understand atau memahami adalah kemampuan membangun makna dari pesan pembelajaran dan mampu mengkomunikasikannya dalam bentuk lisan, tulisan maupun grafik. Siswa memahami ketika mereka mampu menentukan hubungan antara pengetahuan yang baru diperoleh dengan pengetahuan mereka sebelumnya.

Soal yang digunakan untuk menganalisis kemampuan memahami siswa terkait dengan indikator understand disajikan pada butir soal nomor 4 berikut.

\section{Soal nomor 4}

4. Sherly memerik 14 buah mangga. Iwan memetik 20 buah mangga. Perbandingan buah manga yang dipetik Sherly dan Iwan adalah...

Berikut disajikan hasil pekerjaan mahasiswa S4 dan S16 terkait proses pekerjaan dapat dilihat pada gambar 2 berikut.

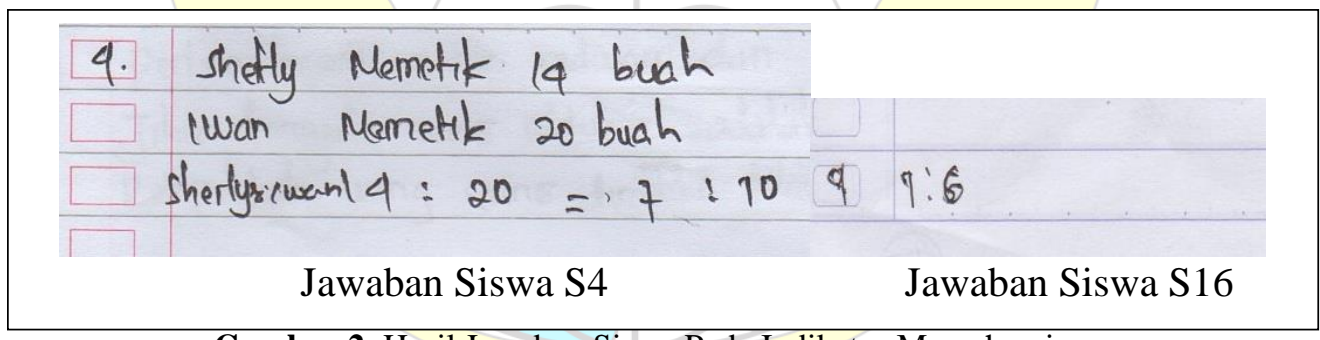

Gambar 2. Hasil Jawaban Siswa Pada Indikator Memahami

Indikator understand hanya dapat dicapai oleh siswa S4. Sedangkan siswa S16 yang merupakan subjek dari kategori kemampuan rendah belum dapat mencapai indikator tersebut. Siswa S4 telah mampu memahami makna yang terdapat pada soal. Rumus yang digunakan oleh siswa S4 tepat, subjek juga terlihat mengetahui hasil perbandingan yang ditanyakan pada soal. Sedangkan siswa S16 belum mampu mencapai indikator ini. Siswa S16 dapat mengerjakan soal tersebut tetapi jawaban dari soal tidak benar dan terlihat siswa S16 belum mampu memahami soal dengan baik. Kemudian dilakukan wawancara untuk mengkonfirmasi jawaban dari S4 dan S16. Berdasarkan hasil wawancara yang dilakukan diperoleh bahwa siswa S4 dalam mengerjakan soal terkait indikator memahami atau understand dapat menyelesaikan soal tersebut. Siswa S4 memahami dalam mengerjakan soal ketika ditanya caa dalam menyelesaikan soal tersebut menjawab dengan menggunakan konsep dari perbandingan dimana membandingkan secara langsung apa yang diketahui dari soal sehingga siswa tersebut mencapai indikator memahami atau understand. Sedangkan siswa S16 ketika ditanya cara dalam 
Dwi Oktaviana ${ }^{1}$, Iwit Prihatin ${ }^{2}$ : Analisis Hasil Belajar Siswa pada Materi Perbandingan Berdasarkan Ranah Kognitif Revisi Taksonomi BLOOM

menyelesaikan soal menjawab tidak memahami cara menyelesaikan soal sehingga dapat dikatakan siswa S16 tidak mencapai indikator memahami atau understand.

Sehingga dapat disimpulkan bahwa setelah dilakukan analisis data terhadap hasil jawaban siswa dan wawancara yang dilakukan bahwa kelemahan siswa dalam menyelesaikan soal terkait indikator memahami atau understand adalah tidak mengerti menggunakan konsep perbandingan sehingga kesulitan dalam menjawab soal. Hal ini sejalan dengan penelitian Priyanto, dkk (2015) yang menyatakan bahwa dari siswa yang diteliti terdapat sebanyak $46 \%$ siswa yang kurang memahami soal.

Apply atau menerapkan adalah kemampuan menggunakan prosedur untuk menyelesaikan masalah. Soal yang digunakan untuk menganalisis kemapuan menerapkan siswa terkait dengan indikator apply disajikan pada butir soal 1, 2, 3, dan 5 berikut.

\section{Soal nomor $1,2,3$, dan 5}

1. Perbandingan uang Ridwan dan Naila adalah 5:8. Jika ternyata uang Ridwan adalah Rp. 200.000,00. Berapakah uang yang dimiliki Naila?
2. Uang Rani dan Tiara berjumlah Rp 250.000,00. Jika uang Rani adalah Rp 95.000,00. Maka pebandingan uang yang dimiliki Rani dan Tiara?

3. Zara sewaktu liburan naik travel menuju Jakarta dengan waktu 3 jam. Nadia menempuh perjalanan yang sama dengan waktu 4 jam. Jika ternyata Nadia waktu di perjalanan melihat speedometer mobil dan ternyata kecepatan mobil Nadia selalu $60 \mathrm{~km} / \mathrm{jam}$. Berapakah kecepatan mobil travel Zara?

5. Jarak kota A ke kota B di peta adalah $8 \mathrm{~cm}$. Pada peta tertera 1 : 500.000 maka jarak sesungguhnya adalah...

Berikut disajikan hasil pekerjaan mahasiswa S4 terkait indikator apply terkait proses pekerjaan dapat dilihat pada gambar 3 berikut.

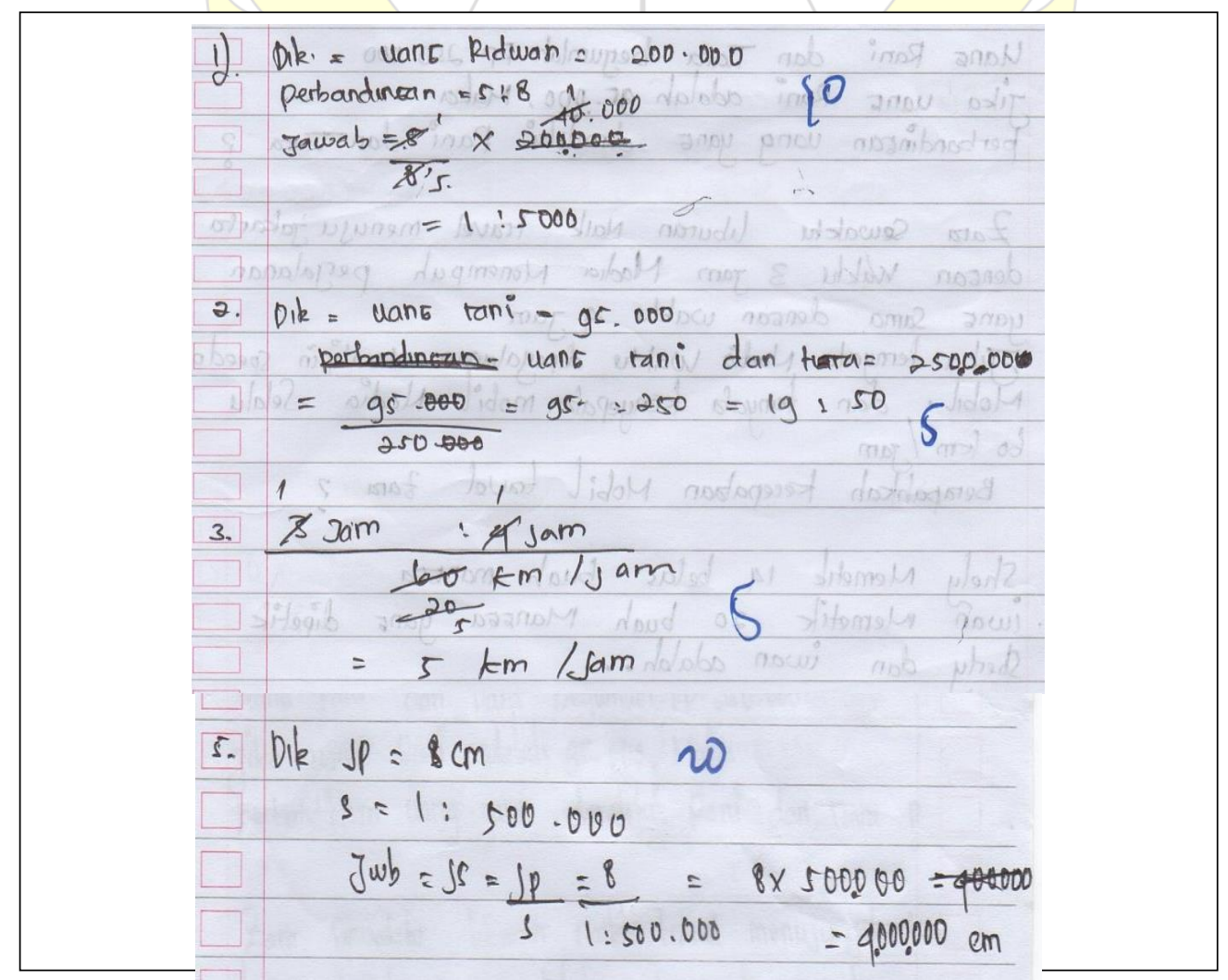

Gambar 3. Hasil Jawaban Siswa S4 Pada Indikator Menerapkan/Apply 
Indikator apply hanya dapat dicapai oleh siswa S4. Siswa tersebut mengerjakan soal nomor 1 dan nomor 5 cukup baik namun pada soal nomor 2 dan nomor 3 siswa belum dapat menyelesaikan soal dengan benar. Siswa S4 dapat menerapkan konsep perbandingan untuk mengerjakan soal nomor 1 dan nomor 5 yang disajikan namun pada soal nomor 2 dan nomor 3 siswa belum mampu mengerjakan soal dimana siswa tidak memahami perintah soal serta tidak dapat menerapkan konsep perbandingan berbalik nilai.

Berikut disajikan hasil pekerjaan mahasiswa S16 terkait indikator apply terkait proses pekerjaan dapat dilihat pada gambar 4 berikut.

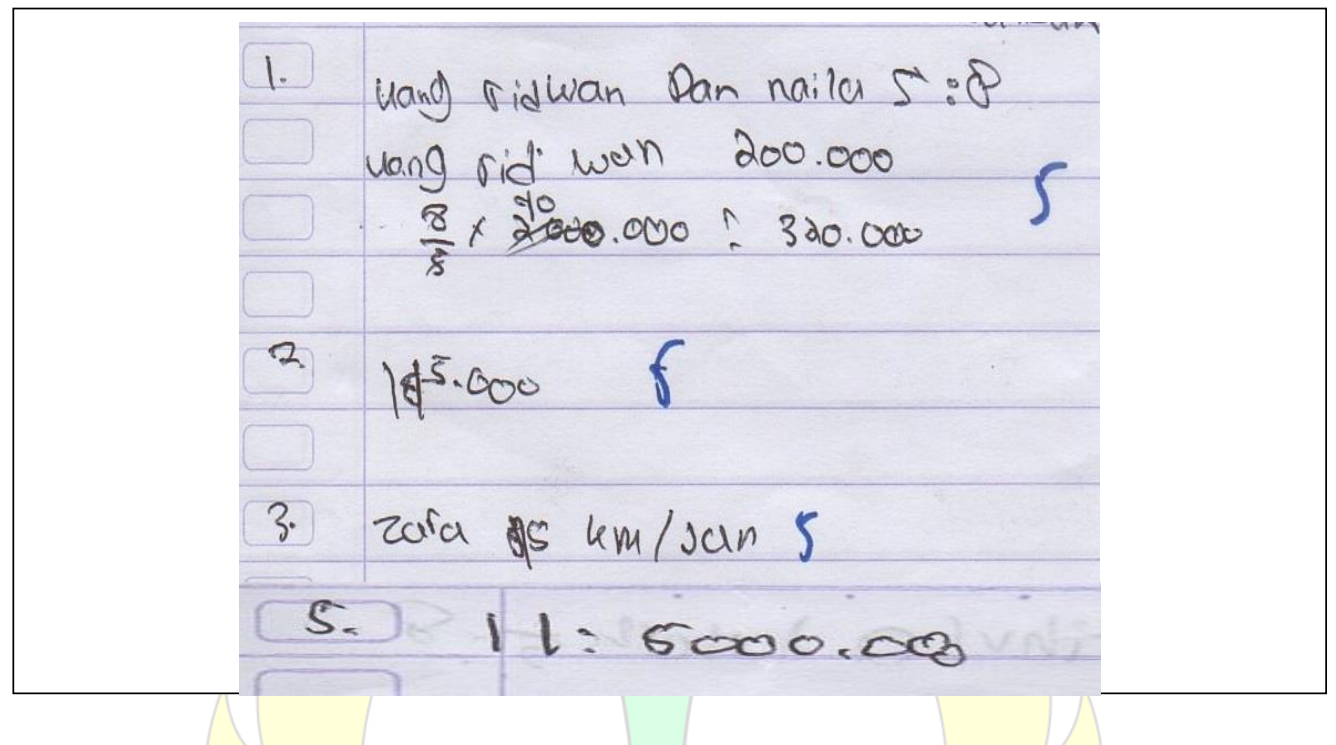

Gambar 4. Hasil Jawaban Siswa S16 Pada Indikator Menerapkan/Apply

Siswa S16 belum mampu mencapai indikator ini. Siswa S16 hanya dapat mengerjakan soal nomor 1 tetapi jawaban dari soal tidak benar dan terlihat siswa S16 sudah mencoba menerapkan konsep perbandingan namun jawaban siswa belum tepat. Terlihat dari jawaban siswa diperoleh hasil yang hanya asal menjawab soal tanpa menuliskan proses untuk menjawab soal.

Kemudian dilakukan wawancara untuk mengkonfirmasi jawaban dari S4 dan S16. Berdasarkan wawancara yang dilakukan diperoleh informasi bahwa siswa S4 ketika ditanya cara dalam menyelesaikan soal maka siswa tersebut menjawab dalam mengerjakan soal dengan menggunakan konsep dari perbandingan yang berkaitan ketika soal tersebut berkaitan dengan perbandingan senilai maka siswa menggunakan konsep perbandingan senilai begitu juga untuk perbandingan berbalik nilai dapat dikatakan siswa S4 telah dapat menerapkan konsep perbandingan dalam mengerjakan soal atau mencapai indikator menerapkan atau apply. Sedangkan siswa S16 ketika ditanya cara dalam menyelesaikan soal maka siswa tersebut menjawab sama sekali tidak memahami cara menyelesaikan soal tetapi untuk soal nomor 1 siswa mencoba menerapkan konsep perbandingan tetapi masih belum menerapkan konsep perbandingan tersebut dengan baik sehingga dapat dikatakan siswa S16 tidak mencapai indikator menerapkan atau apply.

Sehingga dapat disimpulkan bahwa menurut triangulasi data hasil tes siswa dan wawancara yang dilakukan bahwa siswa dengan kemampuan rendah belum mencapai indikator menerapkan atau apply dikarenakan dalam menyelesaikan soal masih bingung menerapkan konsep dari perbandingan yang didapat dengan soal yang terkait, sedangkan siswa dengan kemampuan tinggi sudah mencapai indikator tersebut dimana sudah dapat menerapkan konsep perbandingan dalam menjawab soal. 
Dwi Oktaviana ${ }^{1}$, Iwit Prihatin ${ }^{2}$ : Analisis Hasil Belajar Siswa pada Materi Perbandingan Berdasarkan Ranah Kognitif Revisi Taksonomi BLOOM

Perbedaan tingkatan berpikir inilah yang menyebabkan hasil pekerjaan siswa juga berbeda. Hal ini sesuai dengan yang diungkapkan oleh Radmehr dan Alamoldaei (2010) bahwa ada perbedaan antara kinerja matematika siswa di masing-masing kategori dimensi pengetahuan sesuai dengan proses kognitif dalam taksonomi bloom revisi.

\section{PENUTUP}

\section{Simpulan}

Berdasarkan hasil penelitian dan pembahasan maka dapat diperoleh beberapa kesimpulan sebagai berikut: (1) klasifikasi soal ulangan harian kelas VII B pada materi perbandingan berdasarkan ranah kognitif Taksonomi Bloom Revisi sudah memuat soal dengan indikator pemahaman atau understand sebesar $20 \%$ dan indikator menerapkan atau apply sebesar $80 \%$, (2) hasil belajar siswa berdasarkan ranah kognitif Taksonomi Bloom Revisi adalah siswa lebih mampu menyelesaikan soal dengan indikator pemahaman atau understand sebesar $60 \%$ daripada soal dengan indikator menerapkan atau apply sebesar 19,2\% dimana siswa dengan kemampuan sudah mencapai indikator memahami maupun menerapkan sedangkan siswa dengan kemampuan rendah tidak mencapai kedua indikator.

\section{DAFTAR PUSTAKA}

Anderson dan Kratwohl. 2010. Kerangka Landasan untuk Pembelajaran Pengajaran dan Asesmen (Cetakan ke-1). Yogyakarta: Pustaka Belajar.

Giani., Zulkardi., dan Cecil Hiltrimartin. 2015. “Analisis Tingkat Kognitif Soal-soal Buku Teks Matematika Kelas VII Berdasarkan Taksonomi Bloom.” Jurnal Pendidikan Matematika 9(2): 78-98.

Karwono, H. M. 2012. Belajar dan Pembelajaran. Jakarta: Raja Grafindo Persada

Priyanto, dkk. 2015. “Analisis Kesalahan Siswa dalam Menyelesaikan Soal Cerita Matematika Pokok Bahasan Teorema Puthagoras berdasarkan Kategori Kesalahan Newmann di Kelas VIII A
SMP Negeri 10 Jember." Artikel Ilmiah Mahasiswa I(1): 1-5.

Rahmedr, Farzad. dan Hassan Alamolhodaei. 2010. “A study on The performance of Student's Mathematical Problem Solving Based on Cognitive Process of Revised Bloom Taxonomy." Journal of The Korea Society of Mathematical Education Series D: Research in Mathematical Education 14(4): 381-402.

Uno, H. B. \& Koni, S. 2012. Assessment Pembelajaran. Jakarta: Bumi Aksara. 